\title{
ENHANCING ORAL PROFICIENCY USING THREE STEPS INTERVIEW TECHNIQUE FOR ELEVENTH GRADERS
}

\author{
${ }^{1}$ Dhena Usthiana Haryanti, ${ }^{2}$ Rohmani Nur Indah, \& ${ }^{3}$ Sri Wahyuni \\ ${ }^{1}$ English Student, Department of English Language Education, IAIN Kediri, Indonesia \\ ${ }^{2}$ English Lecturer, Department of English Literature, Universitas Islam Negeri Maulana \\ Malik Ibrahim Malang, Indonesia \\ ${ }^{3}$ English Lecturer, Department of English Language Education, IAIN Kediri, Indonesia \\ Corresponding author Email: haryantidhena@gmail.com
}

\begin{tabular}{|c|c|}
\hline Article Info & Abstract \\
\hline $\begin{array}{l}\text { Article History } \\
\text { Received: December } 2020 \\
\text { Revised: December } 2020 \\
\text { Published: January } 2021\end{array}$ & $\begin{array}{l}\text { Enhancing students' abilities and potential is an important thing that every } \\
\text { teacher must do gradually. The ability to speak in a foreign language is one of } \\
\text { the skills that must be developed, which will benefit students in their learning } \\
\text { process. The aim of this study is to enhance students' oral proficiency using }\end{array}$ \\
\hline $\begin{array}{l}\text { Keywords } \\
\text { Speaking Skill; } \\
\text { Three Steps Interview; } \\
\text { Cooperative Learning; }\end{array}$ & $\begin{array}{l}\text { Three steps interview technique for eleventh-grade students. Quasi-Experimental } \\
\text { research design as a method applied in this study, to determine whether students } \\
\text { are learning to use the technique Three Steps Interview has the ability to speak } \\
\text { that better than the students who are taught using the technique of group } \\
\text { discussion. This research involves two classes divided into an experimental class } \\
\text { and a control class with } 32 \text { students in each class. Students received special } \\
\text { treatment in the experimental class, namely, using the Three Steps Interview } \\
\text { technique, while in the control class, the researcher applied the Group } \\
\text { Discussion technique. The instrument used in testing students' oral proficiency } \\
\text { was using a pretest before implementing learning techniques in each class and } \\
\text { doing a posttest after applying learning techniques. The data analysis results } \\
\text { showed that p(0.000)< significance level (0.05), which means that Three Steps } \\
\text { Interview has significant effect as cooperative learning on oral proficiency, } \\
\text { motivation and enthusiasm during the learning process. Thus, students can easily } \\
\text { express their ideas and opinions confidently. }\end{array}$ \\
\hline
\end{tabular}

How to cite: Haryanti, D. U.\& Indah, R.N (2021). Enhancing Oral Proficiency Using Three Steps Interview Technique for Eleventh Graders. JOLLT Journal of Languages and Language Teaching 9(1), 61-68. DOI: https://doi.org/ 10.33394/jollt.v\%vi\%i.3271

\section{INTRODUCTION}

In recent years, most people prioritize speaking English skills used in communication in education, culture, information, technology, and even science. Therefore, communication ability is essential to be developed, especially in English. Moreover, students can understand the latest information and issues, especially in the international context. It is increasingly undeniable that English is a dominant global language and is used intensively (Setyarini, 2020).

On proses English language teaching and learning in the classroom, speech becomes important to note, especially for the educators. Based on previous research conducted by Setyarini (2020), it is explained that students at school are more focused on exploring reading and writing skills rather than proficiency in speaking English orally. Unfortunately, in practice, learning methods are applied in the classroom and are generally only used to attract students' interest in learning English without the learning process's achievement more specifically. In general, the learning process of speaking, in general, is that the teacher asks 
students to practice the dialogue they have written based on predetermined topics. It is not appropriate to do this because several components must be considered in developing students' oral proficiency. In general, the obstacles faced by EFL learners in Indonesia include a lack of vocabulary, improper pronunciation of words, a lack of self-confidence, and also a lack of curriculum development focused on students' oral proficiency in English (Wahyuningsih \& Afandi, 2020).

Five components must be considered in testing oral proficiency: grammar, vocabulary, comprehension, pronunciation, and fluency (Brown, 2001). Meanwhile, not all teachers use appropriate learning methods to improve students' oral proficiency, especially paying attention to the components of speaking. The ability to speak is an interactive process in arranging words that involve producing and receiving information (Bailey, 2005). Thus, the use of cooperative learning is needed to maximize oral proficiency through interactive learning.

The cooperative learning process allows students to interact with each other in better and more active learning in groups during the learning process (Stone, 1990). Based on this theory, cooperative learning can provide more space for students to develop their ideas, express opinions, and even argue with each other. Students' benefits will be felt, increasing interaction and motivation in students (Candraloka, 2016). Cooperative learning activities, such as indirectly, will also increase student motivation. In this case, they are responsible for themselves. However, they must also focus on their study partners' speaking ability to create a more conducive and effective learning atmosphere. So, their speaking interaction will also be more intensive.

In creating a cooperative learning atmosphere, several learning techniques can be applied in the classroom to improve oral proficiency, one of which is the Three Steps Interview. In developing students' oral proficiency, generally, the teachers will ask students to practice the conversations they have worked on based on predetermined topics. According to Kagan, the Three Steps Interview is a cooperative learning strategy, where students also have to listen to and understand what the other person is discussing (Kagan, 1994). In this case, students must pay close attention to the topics being discussed during the learning process.

Besides that, the Three Steps Interview is a group learning strategy that can improve students' communication skills, group work, and even improve their critical thinking skills through the discussions they conduct. The learning technique using the Three Steps Interview requires students to interact as interviewers and resource persons in its application. The steps taken were that students had to take turns to be interviewers and resource persons in one discussion topic. Besides, students also have to explain back the information they got from the interlocutor. The learning strategy using three-step interviews is considered effective because students can express their language skills freely and courageously (Maca, 2020). Adopting this learning strategy can positively impact interest and motivation so that students have high enthusiasm in the learning process to speak (Umami, 2019; Aristy et al., 2019; Kamaliah et al., 2018).

The benefit of applying the Three Steps Interview technique is to increase their ability to dialogue, especially in understanding and synthesizing new information they hear. Thus, using this strategy can help students learn to discuss orally according to the applied learning topic without using correct or definite answers (Kagan, 1994). There are several advantages and disadvantages to applying this learning technique. The advantages of using the Three Steps Interview technique include developing students' oral proficiency through verbal communication and increasing students' enthusiasm and interest during the learning process due to a fun and effective learning atmosphere (Lipton \& Wellman, 1998). Another advantage is that it improves student groups' performance, where students are required to be cooperative during the learning process. Students will get used to an effective learning 
process and develop cognitive abilities, psychomotor, and students will be more competent, especially for EFL areas (Kamaliah et al., 2018).

On the other hand, this learning technique has a drawback, namely the need for a long time to apply it. The application of the Three Steps Interview cannot be carried out only at one time. However, it must be done repeatedly so that students are familiar with the learning stages and can follow the learning process to improve their oral proficiency. Based on this situation, it would be better if the teacher has prepared media and materials adjusted to the syllabus applied at school (Wulandari, 2017). Previous research explained that the learning process to speak in English is not difficult to learn as long as students understand the steps or strategies they have to do, and this must be done repeatedly (Lingga et al., 2020).

In conducting this research, several problem formulations have been compiled by the researcher. The formulations of the problem are (1) Do students who learn to use the Three Steps Interview technique get better speaking scores than students who are taught using Group Discussion? (2) Can the Three Steps Interview learning strategy improve the students' speaking ability effectively? This study's main purpose is to explain the effective technique applied in the classroom, particularly in developing their speaking ability in English. Through proper and not boring learning methods, it will indirectly motivate students and influence student learning outcomes. Besides that, by creating a pleasant learning atmosphere, students will be more comfortable during the learning process.

\section{RESEARCH METHOD \\ Research Design}

The quasi-experimental research method was used to find the Three Steps Interview's effectiveness in improving students' oral proficiency. There are two variables in this study, namely the independent variable and the control variable. Three Steps Interview as an independent variable, while the students' speaking ability is variable controlled. Meanwhile, this research was conducted at SMAN 1 Plosoklaten, with the research object being students of class XI. There are two classes selected from all existing classes, where students in that class have the same abilities. The researcher determines which class is classified as the experimental class and the control class (Latief, 2019). The experimental class will get specific treatment from researchers, while the control class will not (Ary et al., 2010). In this case, the researcher applied the Three Steps Interview as a learning method in the experimental class, while in the control class, the learning method used was Group Discussion.

\section{Population and Sample}

This study's population was students of class XI SMAN 1 Plosoklaten academic year 2018/2019, which was divided into two departments of science and social studies. The researcher then chose 2 classes randomly, namely class XI IPA 4 and XI IPA 5, as the research sample with 32 students in each class. In applying the treatments, class XI IPA 5 was selected as an experimental class where students would be taught using the Three Step Interview as a learning technique. Meanwhile, the control class, namely XI IPA 4, used the Group Discussion technique. Learning techniques applied to the experimental class and control class aim to provide more opportunities for students to improve their oral proficiency. Thus, the classroom's learning atmosphere will be more enjoyable and foster enthusiasm for students to continue to enhance their oral proficiency.

\section{Instruments}

Before giving treatment to the experimental and control classes, the researcher must pretest the two classes, aiming to determine the students' abilities before getting treatment. Besides, the researcher also had to do a posttest after the treatment was carried out in the two classes, aiming to determine the development or improvement of students' oral proficiency 
after receiving treatment. In conducting the pretest and posttest, researchers used the same technique, where students were asked to practice dialogue with the topics they had randomly assigned. In conducting the pretest, the researcher prepared 10 topics with the theme of natural disasters. In contrast, in conducting the postest, the researcher prepared 10 different topics regarding natural disasters' cause and effect. Details of the teaching and learning process can be seen in Table 1 .

The students' speaking scores are based on five aspects: grammar, vocabulary, fluency, pronunciation, and comprehension. In each aspect of the assessment, there are 5 assessment indicators (ranging from 1-5) that can be used as a reference by researchers in measuring students' speaking ability (Brown, 2001). The technique of assessing students' speaking ability in the pretest and posttest involves totaling the score based on the indicators and total of aspects.

Table 1.

Teaching Procedures

\begin{tabular}{|c|c|}
\hline Experimental Group & Control Group \\
\hline $\begin{array}{l}\text { Opening Activities } \\
\text { - Greeting and praying } \\
\text { - The teacher explains the method and } \\
\text { technique that will use during the class } \\
\text { activities } \\
\text { The teacher explains the material that will be } \\
\text { taught. }\end{array}$ & $\begin{array}{l}\text { Opening Activities } \\
\text { - Greeting and praying } \\
\text { - The teacher explains the method and technique that } \\
\text { will use during the class activities } \\
\text { The teacher explains the purpose of the study. }\end{array}$ \\
\hline $\begin{array}{l}\text { Whilst Teaching Activities } \\
\text { - The teacher explains the material as a } \\
\text { technique in the teaching-learning process } \\
\text { - The teacher makes a group of } 4 \text { students and } \\
\text { labeled the students with A, B, C and D. } \\
\text { - Teacher pairs the students, students A with B } \\
\text { and student C with D. } \\
\text { - The teacher gives a topic to the students in the } \\
\text { group. } \\
\text { - Students are in pairs. Each of them has to be } \\
\text { the interviewer and interviewee. } \\
\text { - Student A interview student B, and student C } \\
\text { interview student B } \\
\text { - After that, students have to reverse roles. } \\
\text { - Each student has to share information with } \\
\text { their team about what they have learned } \\
\text { during the two interviews. }\end{array}$ & $\begin{array}{l}\text { Whilst Teaching Activities } \\
\text { - The teacher explains the material as a technique in } \\
\text { the teaching-learning process } \\
\text { - Teacher discuss and explain more about the material } \\
\text { to the students. } \\
\text { - The teacher gives some topics to practice dialogue } \\
\text { - Students make a group and discuss the dialogue } \\
\text { - Students have to practice the dialogue in front of the } \\
\text { class }\end{array}$ \\
\hline $\begin{array}{l}\text { Closing Activities } \\
\text { - The teacher evaluates the students' practice } \\
\text { - The teacher gives the score to the students } \\
\text { - Praying and ended the classroom }\end{array}$ & $\begin{array}{l}\text { Closing Activities } \\
\text { - The teacher evaluates the students' dialogue practice } \\
\text { - Praying and ended the classroom }\end{array}$ \\
\hline
\end{tabular}

\section{Data Analysis}

The data analysis process covers three stages of analysis carried out by researchers using SPSS. The first step is knowing the descriptive statistics. In the second step, the researcher conducted a homogeneity test using Levene's test to determine the equivalence of students' abilities in both classes, both the control class and the experimental class. If the data on this study is homogeneous, then the researcher can continue the analysis step three, namely using ANCOVA with significant error 0.05. The ANCOVA assumption test was conducted to determine the Three Steps Interview's effectiveness in improving students' oral proficiency (Sujarweni, 2019). 


\section{FINDINGS AND DISCUSSION}

\section{Findings}

This study aimed to enhance students' oral proficiency using Three steps interview technique at eleventh-grade students. This study was designed in experimental design which has control and experimental group. The experimental group was subjected to Three steps interview technique, while the control group was treated using the group discussion technique. The two groups were distributed tests in pre-test and post-test with the same teaching materials. The data were analyzed in statistical analysis, namely, descriptive statistics and inferential statistics. Based on the statistical results of computation using SPSS carried out by researchers, some of the calculation results can be seen in Table 2 .

Table 2

Descriptive Statistics

\begin{tabular}{ccccccc}
\hline & & N & Minimum & Maximum & Mean & $\begin{array}{c}\text { Std. } \\
\text { Deviation }\end{array}$ \\
\hline \multirow{2}{*}{ Pre Test } & Control group & 32 & 20 & 72 & 41.37 & 13.075 \\
\cline { 2 - 7 } & Experiment group & 32 & 36 & 72 & 52.75 & 9.500 \\
\hline \multirow{2}{*}{ Post Test } & Control group & 32 & 52 & 72 & 63.38 & 6.593 \\
\cline { 2 - 7 } & Experiment group & 32 & 72 & 92 & 78.25 & 5.370 \\
\hline
\end{tabular}

The results of statistical calculations in the statistical description table show that the researcher has assessed the students' speaking ability, namely by conducting a pretest and posttest. Table 2 shows that the pretest means score in the control class was 41.32 , while the mean value in the experimental class was 52.75. Then, the posttest average score in the control class was 63.38, while in the experimental class, the average score was 78.25. Thus, it can be seen that the average value posttest students in grade control and experiment are higher than the average value pretest control group and the experimental. In addition, the data were declared as normal and homogeneous data because it was analyzed using Levene's Test. The result can be seen in Table 3. In other words, students who are taugh using Three steps technique are better achievement than those who subjected to the group discussion technique.

Table 3

Levene's Test of Equality of Error Variances

Dependent Variable:Post test

\begin{tabular}{ccccc}
\hline F & df1 & & df2 & Sig. \\
\hline 3.373 & & 1 & 62 & .071 \\
\hline
\end{tabular}

Tests the null hypothesis that the error variance of the dependent variable is equal across groups.

a. Design: Intercept + Group + Pre_Test + Group

* Pre_Test

In Table 3, the significance value shows a value of 0.71 , which is greater than 0.05 . Thus, it can be seen that the abilities of students in the experimental class and control class are not much different. Thus, the data in this study were declared homogeneous and the researcher could continue the data analysis test, namely the ANCOVA assumption test. The results of ANCOVA test can be presented in Table 4 as follows.

Table 4

Tests of Between-Subjects Effects 
Dependent Variable: Post test

\begin{tabular}{lcrrrrr}
\hline \multicolumn{1}{c}{ Source } & $\begin{array}{c}\text { Type III Sum of } \\
\text { Squares }\end{array}$ & Df & Mean Square & \multicolumn{1}{c}{ F } & Sig. & \multicolumn{2}{c}{$\begin{array}{c}\text { Partial Eta } \\
\text { Squared }\end{array}$} \\
\hline Corrected Model & $3542.451^{\mathrm{a}}$ & 2 & 1771.225 & 48.249 & .000 & .613 \\
\hline Intercept & 16963.874 & 1 & 16963.874 & 462.107 & .000 & .883 \\
\hline Group & $\mathbf{2 7 4 8 . 7 7 9}$ & $\mathbf{1}$ & $\mathbf{2 7 4 8 . 7 7 9}$ & $\mathbf{7 4 . 8 7 9}$ & $\mathbf{. 0 0 0}$ & $\mathbf{. 5 5 1}$ \\
\hline Pre_Test & 2.201 & 1 & 2.201 & .060 & .807 & .001 \\
\hline Error & 2239.299 & 61 & 36.710 & & & \\
\hline Total & 326704.000 & 64 & & & & \\
\hline Corrected Total & 5781.750 & 63 & & & & \\
\hline a. R Squared =,613 (Adjusted R Squared $=, 600)$ \\
\hline
\end{tabular}

In table 4, several conclusions can be drawn. The first is the corrected model, which is the independent variable's influence (Three Steps Interview) on the dependent variable (students' speaking ability). If, known sig. 2-tailed (0.000), which is lower than the significance level (0.05), it can be concluded that the independent variable has a significant effect on the dependent variable. The second point is the intercept, which results from changes in the dependent variable without any influence from the existence of the independent variable. If ( $\mathrm{sig}$.) $>0.05$, then the intercept result is significant. However, based on the table above, the sig. (0.000), then the intercept is declared insignificant.

The next point is the group, which explains the Three Steps Interview's effectiveness in improving students' abilities. If it is known (sig.) $<0.05$, then the result is significant. In table 4 , it is known that the significant result for the group is 0.000 . Thus, if $p(0.000)$ <significance level (0.05), it can be concluded that the Three Steps Interview learning technique is proven to improve students' speaking ability effectively. Next is the double determination of the dependent and controlled variables, which shows that the squared RS is 0.6., Which is almost close to 1 , so it can be said that the two variables in this study have a strong correlation with each other.

\section{Discussion}

This research was conducted to find out two things. First, knowing whether students who learn using the Three Steps Interview technique have better oral proficiency than students who are taught using the group discussion technique. Furthermore, this study was conducted to determine the Three Steps Interview learning technique's effectiveness in improving students' oral proficiency. This strategy is one of the learning strategies that fall within the scope of cooperative learning. The tendency to learn in groups can improve students 'socialization skills, develop ideas about learning topics, and effectively develop students' communication skills (Permansari, 2014). Also, students must work together in every lesson, which must be responsible for teamwork and themselves. At the same time, achieving the main objectives of learning (Sonthara \& Vanna, 2009).

This results of this study also are supported by Zainuddin's (2018) findings that the Three Steps Interview learning strategy is considered effective in overcoming students' difficulties to understand and respond to conversations in English. As for the difference, Zainuddin ( 2018) uses the Classroom Action Research design to help students speak based on recount text. Meanwhile, there is also an effective Group Discussion compared to the Three Steps Interview technique. Group Discussion is considered effective because it gets an effective response from students (Danarwati, 2018), supported by learning media (Hussin et al., 2020), especially if it involves small groups (Al Jawad \& Abosnan, 2020; Bohari, 2020; 
Fauzi, 2017). However, when compared to the Three Steps Interview technique, it is still not comparable.

Speaking ability is very important to learn because it affects students' learning success (Suadiyatno, Firman, Hanan, \& Sumarsono, 2020). Therefore, the Three Steps Interview is an effective learning strategy to improve students' speaking ability. Through the learning process, fun and not boring, it would indirectly motivate students to give their understanding and awareness of the importance of the development of the ability to speak in a foreign language. Also, a learning strategy is as effective to increase the confidence of students in speech (Lewis, 2020), especially in the aspects of grammar and comprehension (Kamaliah, et al., 2018), helps students in the description as well as increasing interest and the interest of students in developing and deepen their oral proficiency, through effective teaching and learning activities and the creation of a pleasant learning atmosphere (Aristy, et al., 2019). Thus, the teaching technique using the Three Steps Interview is a learning technique that is proven to increase student interest in learning, increase self-confidence and create an atmosphere of teaching and learning that is both effective and fun to do.

\section{CONCLUSION}

This research was conducted to determine the effectiveness of the Three Steps Interview learning strategy in enhancing the oral proficiency of grade 11 high school students. Based on the research results, it is known that the Three Steps Interview has been shown to improve students' speaking ability effectively and significantly, especially for EFL learners. Students need to learn in a fun atmosphere during the learning process of teaching, not a monotonous. They can increase their motivation to learn so that the necessary systems and effective cooperative learning. Given how crucial the results of this study are, many aspects need to be considered in supporting student learning success. Thus, the use of the Three Steps Interview learning technique can be used by teachers to improve students' oral proficiency while at the same time fostering student interest in continuing to learn and pursuing oral proficiency, which is very useful in this modern era.

Every educator and researcher must continuously update the learning strategies applied in the classroom to support the learning process and student achievement by using supportive and interesting teaching and learning techniques. By creating a comfortable learning atmosphere for students, of course, will have a positive influence on student learning development as well as trigger students to have higher learning motivation. Thus, the development and renewal of learning strategies in the classroom are significant to pay attention to, given the development of current issues in the world of education that continues to roll.

\section{REFERENCES}

Al Jawad, A., \& Abosnan, S. (2020). The Impact of USing Small Group DIscussion Technique on Enhancing Students' Performance in Speaking Skill: A Case Study of Benghazi University. International Journal of Linguistic, Literature and Translation, 189-198.

Aristy, I., Hadiansyah, R., \& Apsari, Y. (2019). Using Three Step Interview to Improve Students' Speaking Ability . Professional Journal of English Education, 74 - 79.

Ary, D., Jacobs, L., \& Sorensen, C. a. (2010). Introduction to Research in Education Eighth Edition. Wadsworth: Cengage Learning .

Bailey, S. (2005). A Handbook for International Students. New York: Routledge .

Bohari, L. (2020). Improving Speaking Skill Through Small Group Discussion of Eleventh Grade Students of SMA Plus Minuril Arifin NW Praya. JOLLT Journal of Languages and Language Teaching, 68-81. 
Brown, H. D. (2001). Teaching by Principles An Interactive Approach to Language Pedagogy. New Jersey: Longman.

Candraloka, O. R. (2016). Implementing Three Steps Interview in Teaching Speaking. Journal Edulingua, 39-46.

Danarwati, R. (2018). Students Perceptions on the Use of Group Discussion Technique in Speaking Sessions of Speaking 1. Yogyakarta: Universitas Sanatha Dharma.

Fauzi, I. (2017). Improving Students Speaking Ability Through Small Group Discussion . Journal ELT Research: The Academic Journal of Studies in English Language Teaching and Learning, 130-138.

Hussin, R., Gani, S., \& Muslem, A. (2020). The Use of Youtube Media Through Group Discussion in Teaching Speaking. English Education Journal, 19-33.

Kagan, S. (1994). Cooperative Learning. San Clement: Kagan Publishing.

Kamaliah, N., Kasim, U., \& Azis, Z. A. (2018). Use of Three Step Interview Technique in Teaching ESL Speaking. English Education Journal , 82-101.

Latief, M. A. (2019). Research Methods on Language Learning An Introduction. Malang: Universitas Negeri Malang.

Lingga, L. M., Simanjuntak, R. M., \& Saragih, E. (2020). Students' Strategies in Learning Speaking Skills at SMP Nasrani 3 Medan. JOLLT Journal of Languages and Language Teaching, 91-99.

Lipton, L., \& Wellman, B. (1998). Mentoring Mtters: A Practical Guide to Learning Focus Relationship. Sherman: MiraVIa LLC.

Maca, S. (2020). Teaching English Speaking Skill through Pair and Group Interview. Ethical Lingua: Journal of Language Teaching and Literature.

Permansari, R. C. (2014). Improving Students' Speaking Skill Through Three Steps Interview Technique. Semarang State University.

Setyarini, S. M. (2020). "I start learning English through speaking" : Social Agency Demand and Inter-School Readiness for Indonesian Young English Learners. Indonesian Journals of Applied Linguistic, 218-225 .

Sonthara, K., \& Vanna, S. (2009). Cooperative Learning: Theory and Practice. Boston: World Education, Inc.

Stone, J. (1990). Cooperative Learning and Language Arts . California : University of California .

Suadiyatno, T., Firman, E., Hanan, A., \& Sumarsono, D. (2020). Examining the Effect of Contextual Teaching-Learning and Anxiety Towards Students' Speaking Skills. JOLLT Journal of Languages and Language Teaching, 100-107.

Sugianto, N. (2020). The Use of Three Steps Interview to Increase Students' Self Confidence at Speaking Skill. Cordova Journal, 84-94.

Sujarweni, V. W. (2019). SPSS untuk Penelitian. Yogyakarta: Penerbit Pustaka Baru Press .

Umami, M. (2019). The Use of Three Steps Interview Technique to Improve Students Speaking Skill for the Tenth Grade of SMK Muhammadiyah Salatiga in the Academic Year 2019/2020. Doctoral Dissertation, IAIN SALATIGA.

Wahyuningsih, S., \& Afandi, M. (2020). Investigating English Speaking Problems: Implication for Speaking Curriculum Development in Indonesia. European Journal of Education Research, 967-977.

Wulandari, S. d. (2017). Using Three Steps Interview Technique to Improve Speaking Ability of Senior High School Students. Journal of English Language Teaching , 94-103.

Zainuddin, Z. (2018). Using Three Steps Interview Technique to Improve the Speaking Skill of The non-English Department Students. Journal of English for Academic and Specific Purposes, 14-32. 